ZOOLOGIA 31 (2): 119-125, April, 2014

http://dx.doi.org/10.1590/S1984-46702014000200003

\title{
The feeding habits of the eyespot skate Atlantoraja cyclophora (Elasmobranchii: Rajiformes) in southeastern Brazil
}

\author{
Alessandra da Fonseca Viana ${ }^{1,2} \&$ Marcelo Vianna ${ }^{1}$ \\ ' Laboratório de Biologia e Tecnologia Pesqueira, Instituto de Biologia, Universidade Federal do Rio de Janeiro. Avenida Carlos \\ Chagas Filho 373, Bloco A, 21941-902 Rio de Janeiro, RJ, Brazil. \\ 2 Corresponding author. E-mail: fviana.ale@gmail.com
}

\begin{abstract}
The stomach contents of the eyespot skate, Atlantoraja cyclophora (Regan, 1903), were examined with the goal to provide information about the diet of the species. Samples were collected off the southern coast of Rio de Janeiro, Brazil, near Ilha Grande, between January 2006 and August 2007, at a depth of about $60 \mathrm{~m}$. The diet was analyzed by sex, maturity stages and quarterly to verify differences in the importance of food items. The latter were analyzed by: frequency of occurrence, percentage of weight and in the Alimentary Index. The trophic niche width was determined to assess the degree of specialization in the diet. Additionally, the degree of dietary overlap between males and females; juveniles and adults and periods of the year were defined. A total of 59 individuals of $A$. cyclophora were captured. Females and adults were more abundant. The quarters with the highest concentrations of individuals were in the summer of the Southern Hemisphere: Jan-Feb-Mar 06 and Jan-Feb-Mar 07. Prey items were classed into five main groups: Crustacea, Teleosts, Elasmobranchs, Polychaeta, and Nematoda. The most important groups in the diet of the eyespot skate were Crustacea and Teleosts. The crab Achelous spinicarpus (Stimpson, 1871) was the most important item. The value of the niche width was small, indicating that a few food items are important. The comparison of the diet between males and females and juveniles and adults indicates a significant overlap between the sexes and stages of maturity; and according to quarters, the importance of prey groups differed (crustaceans were more important in the quarters of the summer and teleost in Jul-Aug-Sep and Oct-Nov-Dec 06), indicating seasonal differences in diet composition. Three groups with similar diets were formed in the cluster analysis: (Jan-Feb-Mar 06 and 07); (Apr-May-Jun 06 and Jul-Aug-Sep 07); (Jul-Aug-Sep 06 and Oct-Nov-Dec 06).
\end{abstract}

KEY WORDS. Diet; elasmobranch; trophic niche; Rajidae; Rio de Janeiro.

Dietary analyses may be used to understand variations in the growth, reproduction, migration and the behavioral aspects of food capture. They may result in increased knowledge of resource sharing and competition between organisms (ROSECCHI \& NouAze 1987), and a broader understanding of trophic ecology, which can be used in ecosystem management (Zavala-CAmiN 1996). Fish diet may differ ontogenetically, spatially and seasonally. For instance, juveniles and adults differ in the size of the food they consume, and differences in food availability may affect the diet of broadly distributed species (ZaVALA-CAMIN 1996).

Elasmobranchs play an important role in marine ecosystems, occupying high trophic levels (EBERT \& BizArRo 2007). They play an important role in the energy flow between the benthic and pelagic regions (Aguiar \& Valentin 2010). As a result of their place in the food chain, benthonic skates may accumulate contaminants such as mercury, and are therefore good indicators of pollution (LACERDA et al. 2000).

Benthonic skates have suffered increased fishing pressure in recent years (MAssA et al. 2006). They are also caught very frequently as bycatch. These two factors make fishery the main anthropogenic factor that affects elasmobranch populations. (Vooren \& Klippel 2005). Overfishing of skates and rays can change the abundance and distribution of their populations, and result in proportional growth of populations of species in lower trophic levels (WALKER \& HisLop 1998).

Studies on the diet of elasmobranchs are less frequent than studies involving other marine fishes. According to Aguiar \& Valentin (2010), only 44 studies on the alimentary biology and ecology of elasmobranchs have been published in Brazilian journals, and only one of these analyzed the diet of Atlantoraja cyclophora (Regan, 1903). Elasmobranchs are carnivorous, eating less variety of prey than the herbivorous or omnivorous teleosts. EBERT \& Bizarro (2007) studied 60 species of Rajiformes and indicated that in the diet of skates, teleosts and decapods are dominant groups. Rajiformes are secondary or tertiary consumers and are classified as benthopelagic or epibenthic predators specialized in marine invertebrates or small crustaceans (Aguiar \& Valentin 2010).

2014 Sociedade Brasileira de Zoologia | www.sbzoologia.org.br | www.scielo.br/zool All content of the journal, except where identified, is licensed under a Creative Commons attribution-type BY-NC. 
The eyespot skate A. cyclophora belongs to Rajidae. This oviparous skate with demersal habits is found in the South Atlantic Ocean, from Rio de Janeiro (Brazil) to the south of the Mar del Plata (Argentina). The species is found from 30 to 300 $\mathrm{m}$ depth (mainly below $50 \mathrm{~m}$ ) (Gomes et al. 2010), generally in cold waters of the continental shelf and upper continental slope, and does not seem to have a preference for any peculiar granulometry of the sediment. Normally, females of $A$. cyclophora are heavier and wider than males (OdDone \& Vooren 2004). The species is caught as bycatch in coastal demersal fisheries, and has suffered growing fishing pressure. As a result, it is considered "vulnerable" in the Red List of the International Union for Conservation of Nature (CHeung et al. 2005). Given the scarcity of studies on A. cyclophora, it is the time for scientists to focus their attention on the species (MAssa et al. 2006).

The goal of this study was to generate information about the diet of Atlantoraja cyclophora in southeastern Brazil, by identifying the main food items to species; and to ascertain differences in the importance of food items according to sex, maturity stages and periods of the year.

\section{MATERIAL AND METHODS}

Between January 2006 and August 2007, 14 samples were hauled from the southern coast of Rio de Janeiro, Brazil, near Ilha Grande (Fig. 1). Each haul lasted one hour, and was conducted at about $60 \mathrm{~m}$ depth. The boat worked with a bottompair trawl. The net had a $20 \mathrm{~mm}$ mesh between opposing knots at the body and sleeves and $18 \mathrm{~mm}$ in codend.

The area of the study is located near the Ilha Grande Bay $\left(22^{\circ} 50^{\prime}-23^{\circ} 20^{\prime} \mathrm{S}, 44^{\circ} 00^{\prime}-44^{\circ} 45^{\prime} \mathrm{W}\right)$, in the southern coast of Rio de Janeiro. The sediment is mainly characterized by medium/ fine sand, but also silt and clay. In this region three water masses occur: Tropical Water, Coastal Water and South Atlantic Central Water. The Tropical Water (TW) occurs in the upper layer, with high temperatures and salinity $\left(\mathrm{T}>20^{\circ} \mathrm{C}, \mathrm{S}>36.4\right)$. The Coastal Water $(\mathrm{CW})$, with high temperature $\left(24^{\circ} \mathrm{C}\right)$ and low salinity (34.9), normally occurs in the inner shelf. The South Atlantic Central Water (SACW) has low temperature and salinity $\left(\mathrm{T}<20^{\circ} \mathrm{C}, 34<\mathrm{S}<36.4\right)$ and can emerge when the wind conditions are favorable for upwelling. Therefore, in late spring and summer, this mass occupies the inner shelf, and in winter and autumn it moves offshore.

After collection, the material was chilled and later frozen until processing. Samples of A. cyclophora were identified according to Gomes et al. (2010), measured (disc width, cm), weighed (total weight, g) and sexed (voucher C.DBAV UERJ1256). Then, the skates were dissected and the maturity stage of each specimen (juvenile or adult) was determined according to a combination of internal and external characteristics (Oddone \& Vooren 2005). The stomachs were removed, weighed, fixed in 10\% formalin and conserved in 70\% ethanol. The stomach contents were analyzed and prey items were

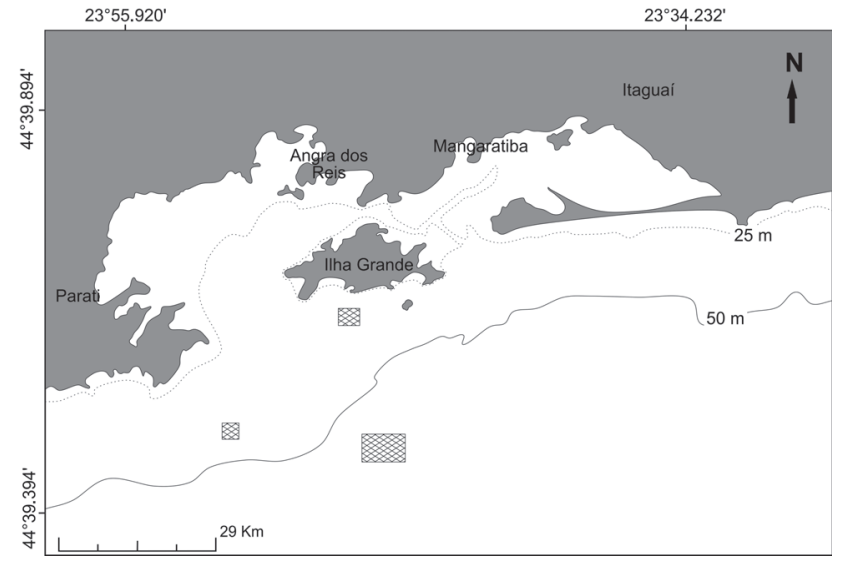

Figure 1. Location of samples taken, between January 2006 and August 2007, near llha Grande, on the southern coast of Rio de Janeiro, Brazil.

weighed and identified to the lowest possible taxonomic level. Identification was made with the help of specialists.

A cumulative prey curve (Cortes 1997, Ferry \& Cailliet 1996) was employed to determine whether the sample was large enough to precisely describe the diet. This method plots the cumulative number of randomly pooled stomachs against the cumulative number of prey types. This curve was constructed using the program EstimateSWin820 and fifty randomizations were performed.

Food items were analyzed by Frequency of Occurrence (\%FO), expressed as the percentage of the stomachs analyzed containing the prey item; and Percentage Weight (\%W), which is the percentage of the weight of the prey item with respect to the total weight of all prey items combined. These measurements were combined in the Alimentary Index (IAi), according to KAWAKami \& VAzzoler (1980), and modified to use the Percentage Weight $(\% \mathrm{~W})$, according to the equation:\% $\% \mathrm{IAi}_{1}=\left(\left(\% \mathrm{FO}_{1}\right.\right.$ $\left.\left.\mathrm{x} \% \mathrm{~W}_{1}\right) / \Sigma\left(\% \mathrm{FO}_{\mathrm{T}} \mathrm{x} \% \mathrm{~W}_{\mathrm{T}}\right)\right) \times 100$, where $\% \mathrm{FO}_{1}=$ percentage of stomachs in which determined item occur; $\% \mathrm{~W}_{1}=$ percentage of weight of determined item. The trophic niche width was determined according to the Standardized Levins Index (HuRlbert 1978) to assess the degree of diet specialization, according to the following equation: $\mathrm{Bi}=\left[\left(\sum j \mathrm{Pij}^{2}\right)^{-1}-1\right](\mathrm{n}-1)^{-1}$, where $\mathrm{Pij}=$ proportion of the prey $\mathrm{j}$ in the diet of the predator $\mathrm{I} ; \mathrm{n}=\mathrm{num}$ ber of prey categories. In order to provide information about prey importance and feeding strategy, an adaptation ofthe Costello's (1990) method by AMUNDSEn et al. (1996) was employed.

The diet was analyzed by sex, maturity stages of the skates and quarterly. The Trophic Niche Overlap Index by PIANKA (1973), was employed to determine the degree of dietary overlap between males and females and juveniles and adults, according to the following equation: Oxy $=\Sigma($ Pxi $x$ Pyi $) / \sqrt{ } \Sigma\left(\Sigma \mathrm{Pxi}^{2}\right.$ $\left.\mathrm{x} \Sigma \mathrm{Pyi}^{2}\right)$, where $\mathrm{Pxi}=$ proportion of prey $\mathrm{i}$ in predator $\mathrm{x}$; Pyi = proportion of prey i in predator $y$. 
In the temporal analyses, six quarters were defined: 1 (Jan-Feb-Mar 06), 2(Apr-May-Jun 06), 3(Jul-Aug-Sep 06), 4(OctNov-Dec 06), 5 (Jan-Feb-Mar 07), 6 (Jul-Aug-Sep/07). The diet was determined for each quarter and a cluster analysis was performed, employing Ward's Method, using the Past Statistic Program to define groups with similar diet.

\section{RESULTS}

We analyzed a total of 59 stomachs of A. cyclophora; of these, two were empty and were not included in the analyses. Of the remaining 57 stomachs, those from females and adults were more abundant (Table I), with disc width ranging from 14.8 to $47.8 \mathrm{~cm}$ (mean $=38.04 \pm 8.25$; median $=40.3$ ). While Jan-Feb-Mar 06 were the quarters with the highest concentration of skates, Apr-May-Jun 06 and Jul-Aug-Sep 07 (Table I) had the lowest concentrations. The cumulative prey curve (Fig. 2) stabilized after about 40 stomachs, indicating that this number was representative for the sampling area.

Table I. Sex ratio according to maturity stages and quarters of the year of Atlantoraja cyclophora, collected in southern coast of Rio de Janeiro, Brazil.

\begin{tabular}{lccc}
\hline & Females & Males & Total \\
\hline Juveniles & 10 & 7 & 17 \\
Adults & 24 & 16 & 40 \\
Jan-Feb-Mar 06 & 14 & 10 & 24 \\
Apr-May-Jun 06 & 0 & 1 & 1 \\
Jul-Aug-Sep 06 & 5 & 2 & 7 \\
Oct-Nov-Dec 06 & 7 & 6 & 13 \\
Jan-Feb-Mar 07 & 8 & 3 & 11 \\
Jul-Aug-Sep 07 & 0 & 1 & 1 \\
\hline
\end{tabular}

Prey items were classified into five main groups (Crustacea, Teleosts, Elasmobranchs, Polychaeta, Nematoda) (Table II). The group Crustacea was the most important in the diet (79.4\%IAi). Teleosts were also important, since this group has a significant FO\%. The crab Achelous spinicarpus (Stimpson, 1871) (= Portunus spinicarpus) was the most important item overall (53.5\%IAi), followed by Portunidae (23.6\%IAi). Item fragments of teleosts were important (9.7\%IAi), and Dactylopterus volitans (Linnaeus, 1758) was a very representative teleost (8.2\%IAi). The trophic niche width of $A$. cyclophora was 0.1 , indicating that a few food items are very important.

The prey importance and feeding strategy diagrams (Figs 3 and 4) show that no food item was dominant in the diet of A. cyclophora. We reached this conclusion because no items occur in area IV of the diagram (Fig. 3). However, two items were the most important, Brachyura and fragments of Teleosts. The other items were rare, because they occur in area III (Fig. 3). When whole groups were taken into consideration, Crustacea were dominant (presence in are IV), but Fishes were

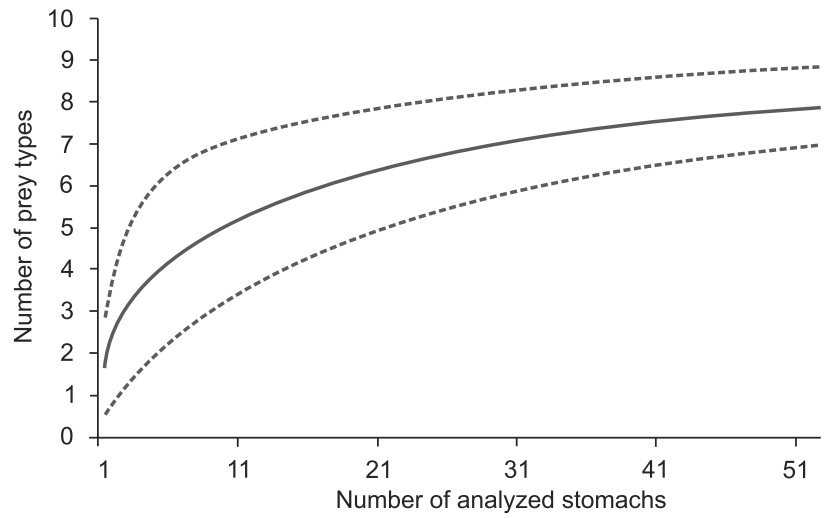

Figure 2. Cumulative prey curve in the diet, of Atlantoraja cyclophora, with a confidence interval of $95 \%$ upper and lower, in southeastern Brazil.
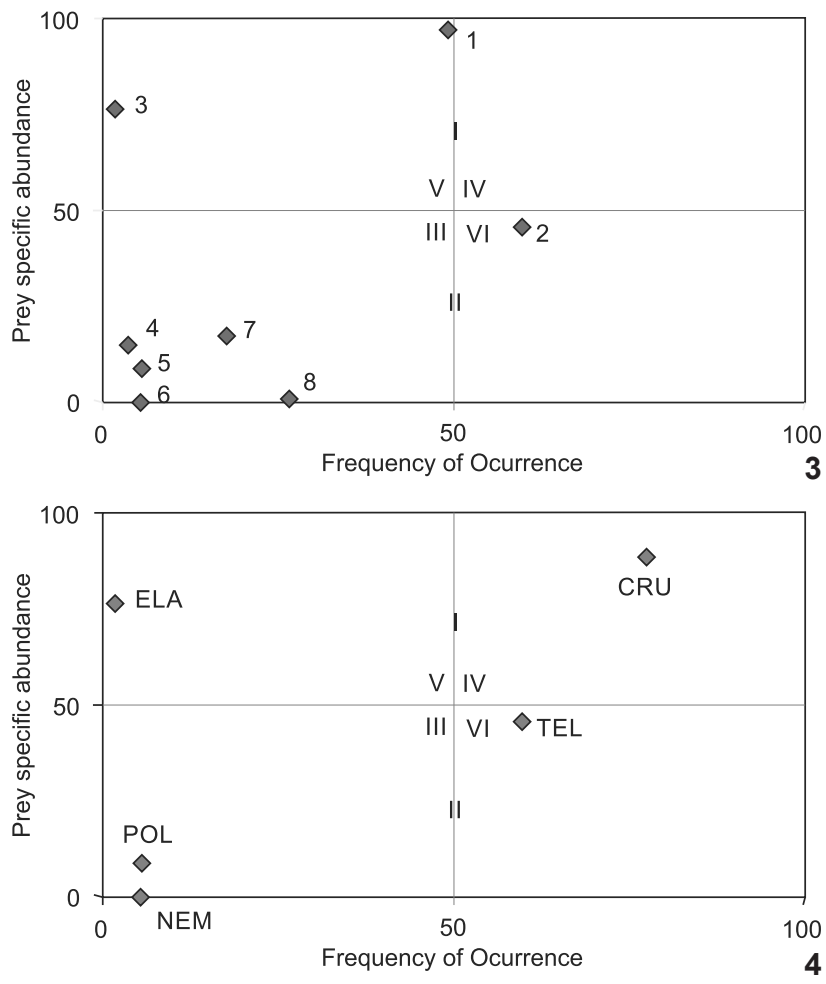

Figures 3-4. Diet of Atlantoraja cyclophora analyzed by Costello's method (1990), adapted by Amundsen et al. (1996), in southeastern Brazil. where: feeding strategy - specialist (I) or generalist (II); importance of prey - rare (III) or dominant (IV) and width of trophic niche - high between phenotype $(V)$ or high within phenotype (VI) by food items (3) and by groups (4). Food items: 1) Brachyura, 2) Teleosts fragments, 3) Rajidae, 4) Stomatopoda, 5) Polychaeta, 6) Nematoda, 7) Caridea/Dendobranchiata, 8) Crustacean fragments. Groups: CRU) Crustacea, TEL) Teleost fishes, ELA) Elasmobranch, POL) Polychaeta, NEM) Nematoda. 
Table II. Frequency of ocurrence (\%FO), percentage weight (\%W) and alimentary index (\%lAi), of prey items in the total diet of Atlantoraja cyclophora, in southeastern Brazil, according to sex (females and males) and stages of maturity.

\begin{tabular}{|c|c|c|c|c|c|c|c|c|c|c|c|c|c|c|c|}
\hline \multirow{3}{*}{ Prey items } & \multicolumn{9}{|c|}{ Sex } & \multicolumn{6}{|c|}{ Stages of maturity } \\
\hline & \multicolumn{3}{|c|}{ Total $(n=57)$} & \multicolumn{3}{|c|}{ Females $(n=34)$} & \multicolumn{3}{|c|}{ Males $(n=23)$} & \multicolumn{3}{|c|}{ Juveniles $(n=17)$} & \multicolumn{3}{|c|}{ Adults $(n=40)$} \\
\hline & $\%$ FO & $\% \mathrm{~W}$ & $\% \mathrm{IAi}$ & $\%$ FO & $\% \mathrm{~W}$ & $\%$ IAi & $\% \mathrm{FO}$ & $\% \mathrm{~W}$ & $\% \mathrm{IAi}$ & $\% \mathrm{FO}$ & $\% \mathrm{~W}$ & $\% \mathrm{IAi}$ & $\% \mathrm{FO}$ & $\% \mathrm{~W}$ & $\% \mathrm{IAi}$ \\
\hline Crustacea & 77.2 & 747.0 & 79.4 & 79.0 & 72.4 & 77.3 & 78.3 & 85.9 & 89.5 & 82.4 & 85.5 & 90.5 & 80.0 & 73.8 & 79.7 \\
\hline Caridea/Dendobranchiata & 5.3 & 0.3 & 0.1 & 2.9 & 0.0 & 0.0 & 8.7 & 1.6 & 0.9 & 11.8 & 2.5 & 1.6 & 2.5 & 0.1 & 0.0 \\
\hline Caridea & 10.5 & 2.1 & 1.3 & 11.8 & 1.5 & 0.9 & 8.7 & 4.6 & 2.7 & 5.9 & 2.4 & 0.8 & 12.5 & 2.0 & 1.2 \\
\hline Dendobranchiata & 1.8 & 0.1 & 0.0 & & & & 4.3 & 0.1 & 0.0 & & & & 2.5 & 0.0 & 0.0 \\
\hline Brachyura & 10.5 & 3.5 & 2.2 & 11.8 & 2.7 & 1.5 & 8.7 & 7.0 & 4.1 & 11.8 & 14.4 & 9.6 & 10.0 & 2.5 & 1.2 \\
\hline Leucosiidae & 1.8 & 1.5 & 0.2 & & & & 4.3 & 8.9 & 2.6 & & & & 2.5 & 1.7 & 0.2 \\
\hline Parthenopidae & 1.8 & 0.1 & 0.0 & & & & 4.3 & 0.4 & 0.1 & & & & 2.5 & 0.1 & 0.0 \\
\hline Portunidae & 14.0 & 27.9 & 23.6 & 14.7 & 25.8 & 18.2 & 13.0 & 37.9 & 33.5 & & & & 20.0 & 30.3 & 28.8 \\
\hline Achelous spinicarpus & 22.8 & 38.9 & 53.5 & 29.4 & 42.0 & 59.2 & 17.4 & 24.4 & 28.8 & 11.8 & 64.8 & 43.1 & 30.0 & 36.8 & 52.3 \\
\hline Stomatopoda & 3.5 & 0.1 & 0.0 & 5.9 & 0.1 & 0.0 & & & & 5.9 & 0.1 & 0.0 & 2.5 & 0.1 & 0.0 \\
\hline Crustacean fragments & 26.3 & 0.3 & 0.5 & 23.5 & 0.1 & 0.1 & 30.4 & 1.1 & 2.3 & 41.2 & 1.4 & 3.4 & 20.0 & 0.2 & 0.2 \\
\hline Teleosts & 59.6 & 25.1 & 20.6 & 61.8 & 27.3 & 22.7 & 56.5 & 14.0 & 10.5 & 64.7 & 11.0 & 9.2 & 57.5 & 26.2 & 20.3 \\
\hline Dactylopterus volitans & 8.8 & 15.5 & 8.2 & 14.7 & 18.7 & 13.2 & & & & & & & 12.5 & 16.8 & 10.0 \\
\hline Teleost fragments & 50.9 & 3.2 & 9.7 & 50.0 & 2.5 & 6.0 & 52.2 & 6.4 & 22.6 & 64.7 & 11.0 & 40.4 & 45.0 & 2.5 & 5.3 \\
\hline Pleuronectiformes & 1.8 & 1.2 & 0.1 & & & & 4.3 & 7.3 & 2.1 & & & & 2.5 & 1.3 & 0.2 \\
\hline Symphurus sp. & 1.8 & 5.1 & 0.5 & 2.9 & 6.1 & 0.9 & & & & & & & 2.5 & 5.5 & 0.7 \\
\hline Polydactylus sp. & 1.8 & 0.1 & 0.0 & & & & 4.3 & 0.3 & 0.1 & & & & 2.5 & 0.1 & 0.0 \\
\hline Elasmobranchs & 1.8 & 0.2 & 0.0 & 2.9 & 0.3 & 0.0 & & & & 5.9 & 3.0 & 0.2 & & & \\
\hline Rajidae & 1.8 & 0.2 & 0.0 & 2.9 & 0.3 & 0.0 & & & & 5.9 & 3.0 & 1.0 & & & \\
\hline Polychaeta & 5.3 & 0.0 & 0.0 & 5.9 & 0.0 & 0.0 & 4.3 & 0.0 & 0.0 & 11.8 & 0.3 & 0.0 & 2.5 & 0.0 & 0.0 \\
\hline Euclymene sp. & 1.8 & 0.0 & 0.0 & 2.9 & 0.0 & 0.0 & & & & 5.9 & 0.1 & 0.0 & & & \\
\hline Sthenelais sp. & 3.5 & 0.0 & 0.0 & 2.9 & 0.0 & 0.0 & 4.3 & 0.0 & 0.0 & 5.9 & 0.2 & 0.1 & 2.5 & 0.0 & 0.0 \\
\hline Nematoda & 5.3 & 0.0 & 0.0 & 2.9 & 0.0 & 0.0 & 8.7 & 0.1 & 0.0 & 11.8 & 0.1 & 0.0 & 2.5 & 0.0 & 0.0 \\
\hline Nematods & 5.3 & 0.0 & 0.0 & 2.9 & 0.0 & 0.0 & 8.7 & 0.1 & 0.0 & 11.8 & 0.1 & 0.1 & 2.5 & 0.0 & 0.0 \\
\hline
\end{tabular}

also important (presence in area VI, with a high frequency of occurrence). Polychaeta and Nematoda were rare (Fig. 4).

The value of dietary overlap between females and males was high, 0.93. In both cases Crustaceans were more important (Table II) (77.3\% IAi and 89.5\% IAi respectively) followed by teleost, which were more heavily represented by females (22.7\% IAi and $10.5 \%$ IAi respectively). Regarding the items, Portunidae (18.2\% IAi for females and 33.5\% IAi for males) and A. spinicarpus (59.2\% IAi for females and $28.8 \%$ IAi for males) were the most important for both sexes. Other items like Caridea and crustacean fragments were more represented in the diet of males (2.7 and 2.3\% IAi respectively).

The value of dietary overlap between juveniles and adults was also quite high, 0.99. In this case, the crustaceans were also more representative for the both stages of maturity (Table II) (90.5 and 79.7\% IAi respectively), followed by teleost (9.2 and $20.3 \%$ IAi respectively). The polychaetes and nematodes were less relevant, but more relevant to juveniles. In both groups A. spinicarpus was the most representative item $(43.1 \%$ IAi for juveniles and 52.3\%.IAi for adults).

The importance of prey groups differed according to season (Table III). The cluster analysis (Fig. 5) indicated that three groups were formed: Group 1 (Jan-Feb-Mar 06 and Jan-Feb-Mar 07); Group 2 (Apr-May-Jun 06 and Jul-Aug-Sep 07) and Group 3 (Jul-Aug-Sep 06 and Oct-Nov-Dec 06), indicating seasonal differences in diet composition. The quarters Jan-Feb-Mar 06 and Jan-Feb-Mar 07 had a great importance of crustaceans (97.3 and 98.9\% IAi respectively), mainly Portunidae and A. spinicarpus. In the quarters of Jul-Aug-Sep 06 and Oct-Nov-Dec 06 teleost were the most representative (57.7 and $63.7 \%$ IAi respectively), especially D. volitans. The quarters, Apr-May-Jun 06 and Jul-AugSep 07 had predominance of crustaceans (76.2 and 100\% IAi respectively), but the number of individuals captured during this period was less representative. 


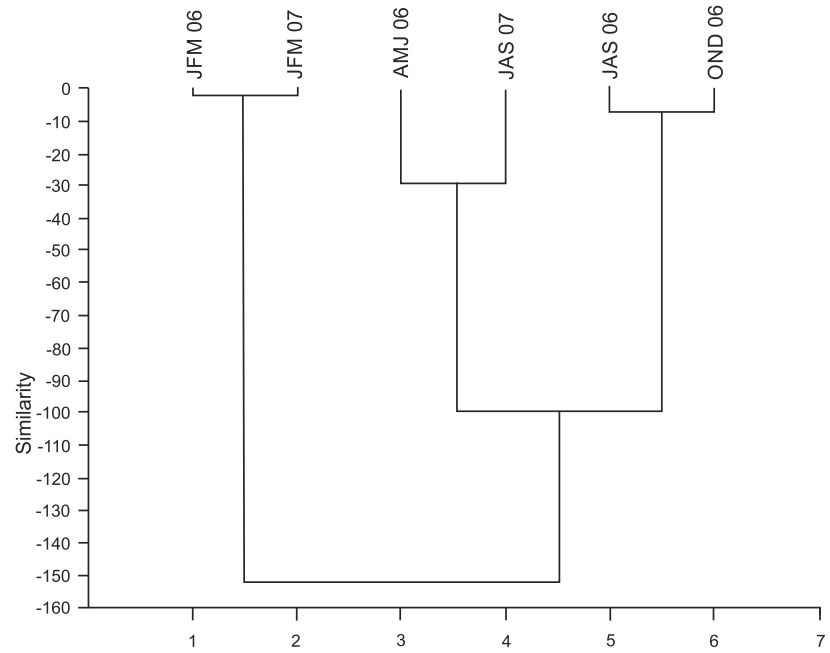

Figure 5. Dendrogram resulting from the cluster analysis, employing Ward's Method, according to quarter, in southeastern Brazil, where JFM correspond to Jan-Feb-Mar; AMJ to Apr-May-Jun, JAS to Jul-Aug-Sep and OND to Oct-Nov-Dec.

\section{DISCUSSION}

Females of $A$. cyclophora were larger at onset of sexual maturity than males, which is in agreement with results of other studies on Rajidae (ODdone \& Vooren 2005, OdDone et al. 2008). Females also reached larger size than males, as observed in other studies with A. cyclophora (Oddone \& Vooren 2004, ODdone et al. 2008). Skates were more abundant in the summer (Jan-Feb-Mar 06 and Jan-Feb-Mar 07). Summer is the season of greatest upwelling of the South Atlantic Central Water (SACW), which generates the oceanographic conditions favored by this species (Oddone \& Vooren 2004).

Atlantoraja cyclophora feeds on benthic prey, mainly crustaceans and teleost. Crabs, mainly $A$. spinicarpus, were the most important item in the diet of A.cyclophora, probably because they are abundant in the area (PIRES 1992). The prey importance and feeding strategy diagrams confirmed these results, showing the dominance of crustaceans in the diet of the skate, followed by teleosts. Our results indicate that the diet of A.cyclophora is specialized. Although the Fishes did not have a high value of Alimentary Index $\left(\% \mathrm{IA}_{\mathrm{I}}\right)$ and was not a dominant item, this group

Table III. Frequency of Ocurrence (\%FO), Percentage Weight (\%W) and Alimentary Index (\%IAi) of prey items in the diet of Atlantoraja cyclophora according to the quarters, in southeastern Brazil.

\begin{tabular}{|c|c|c|c|c|c|c|c|c|c|c|c|c|c|c|c|c|c|c|}
\hline \multirow{2}{*}{ Prey items } & \multicolumn{3}{|c|}{$\begin{array}{c}\text { Jan-Mar } 06 \\
(\mathrm{n}=24)\end{array}$} & \multicolumn{3}{|c|}{$\begin{array}{l}\text { Apr-Jun } 06 \\
(\mathrm{n}=1)\end{array}$} & \multicolumn{3}{|c|}{$\begin{array}{l}\text { Jul-Sep } 06 \\
(n=7)\end{array}$} & \multicolumn{3}{|c|}{$\begin{array}{l}\text { Oct-Dec } 06 \\
(n=13)\end{array}$} & \multicolumn{3}{|c|}{$\begin{array}{c}\text { Jan-Mar } 07 \\
(\mathrm{n}=11)\end{array}$} & \multicolumn{3}{|c|}{$\begin{array}{l}\text { Jul-Sep } 07 \\
(\mathrm{n}=1)\end{array}$} \\
\hline & $\% \mathrm{FO}$ & $\% W$ & IAi & $\% \mathrm{FO}$ & $\% W$ & IAi & $\% \mathrm{FO}$ & $\% W$ & $\mathrm{IAi}$ & $\% \mathrm{FO}$ & $\% W$ & $\mathrm{IAi}$ & $\% \mathrm{FO}$ & $\% W$ & IAi & $\% \mathrm{FO}$ & $\% W$ & IAi \\
\hline Crustacea & 83.3 & 95.6 & 97.3 & 100 & 76.2 & 76.2 & 85.7 & 37.9 & 42.3 & 46.2 & 51.1 & 36.3 & 100 & 97.2 & 98.9 & 100 & 100 & 100 \\
\hline Caridea/Dendobranchiata & 4.2 & 0.6 & 0.1 & 100 & 76.2 & 76.2 & & & & 7.7 & 0.0 & 0.0 & & & & & & \\
\hline Caridea & 4.2 & 0.6 & 0.1 & & & & 57.1 & 6.8 & 17.9 & & & & 9.1 & 0.7 & 0.2 & & & \\
\hline Dendobranchiata & & & & & & & & & & & & & & & & 100 & 66.7 & 66.7 \\
\hline Brachyura & 16.7 & 10.4 & 5.5 & & & & & & & 7.7 & 1.1 & 0.4 & 9.1 & 0.3 & 0.1 & & & \\
\hline Leucosiidae & & & & & & & & & & 7.7 & 9.9 & 3.7 & & & & & & \\
\hline Parthenopidae & & & & & & & & & & 7.7 & 0.4 & 0.1 & & & & & & \\
\hline Portunidae & 4.2 & 11.7 & 1.5 & & & & 28.6 & 30.1 & 39.8 & 7.7 & 14.2 & 5.3 & 36.4 & 50.9 & 67.1 & & & \\
\hline Achelous spinicarpus & 37.5 & 72.2 & 85.7 & & & & 14.3 & 1.1 & 0.7 & 15.4 & 23.9 & 17.7 & 18.2 & 45.0 & 29.7 & & & \\
\hline Stomatopoda & & & & & & & & & & 15.4 & 0.6 & 0.5 & & & & & & \\
\hline Crustacean fragments & 29.2 & 0.2 & 0.1 & & & & 14.3 & 0.0 & 0.0 & 7.7 & 1.0 & 0.4 & 45.5 & 0.3 & 0.5 & 100 & 33.3 & 33.3 \\
\hline Teleosts & 50.0 & 4.4 & 2.7 & 100 & 23.8 & 23.8 & 71.4 & 62.1 & 57.7 & 84.6 & 48.8 & 63.7 & 54.5 & 1.9 & 1.0 & & & \\
\hline Dactylopterus volitans & & & & & & & 14.3 & 36.0 & 23.8 & 23.1 & 40.5 & 45.1 & 9.1 & 0.8 & 0.2 & & & \\
\hline Teleost fragments & 50.0 & 4.4 & 6.9 & 100 & 23.8 & 23.8 & 28.6 & 1.0 & 1.3 & 69.2 & 8.0 & 26.6 & 45.5 & 1.1 & 1.8 & & & \\
\hline Pleuronectiformes & & & & & & & 14.3 & 4.9 & 3.3 & & & & & & & & & \\
\hline Symphurus sp. & & & & & & & 14.3 & 20.2 & 13.3 & & & & & & & & & \\
\hline Polydactylus sp. & & & & & & & & & & 7.7 & 0.4 & 0.1 & & & & & & \\
\hline Elasmobranchs & & & & & & & & & & & & & 9.1 & 0.8 & 0.1 & & & \\
\hline Rajidae & & & & & & & & & & & & & 9.1 & 0.8 & 0.3 & & & \\
\hline Polychaeta & & & & & & & & & & 7.7 & 0.0 & 0.0 & 18.2 & 0.1 & 0.0 & & & \\
\hline Euclymene sp. & & & & & & & & & & 7.7 & 0.0 & 0.0 & & & & & & \\
\hline Sthenelais sp. & & & & & & & & & & & & & 18.2 & 0.1 & 0.1 & & & \\
\hline Nematoda & 4.2 & 0.0 & 0.0 & & & & & & & 7.7 & 0.0 & 0.0 & 9.1 & 0.0 & 0.0 & & & \\
\hline Nematods & 4.2 & 0.0 & 0.0 & & & & & & & 7.7 & 0.0 & 0.0 & 9.1 & 0.0 & 0.0 & & & \\
\hline
\end{tabular}


had a high Frequency of Occurrence (\% FO), particularly in teleost fragments. These values are small because of the low\% $\mathrm{P}$ and prey-specific abundance. Therefore we cannot estimate the true importance of this group. As previously observed by ZaVALACAMIN (1996), Fish are digested more rapidly than other groups that have a carapace, such as crustaceans.

A diet based on crustaceans and teleosts was also observed for a congeneric species, and for A. cyclophora by other authors (SoARes et al. 1992, Bizarro et al. 2007). In a study of the diet of $A$. cyclophora in Ubatuba $\left(23^{\circ} 20^{\prime} \mathrm{S}-24^{\circ} 00^{\prime} \mathrm{S}, 44^{\circ} 30^{\prime} \mathrm{W}-45^{\circ} 30^{\prime} \mathrm{W}\right)$, São Paulo, Brazil, the most important items were crustaceans and teleosts, and Brachyura was also relevant (SOAREs et al. 1992). In the same study, the feeding habits of Raja castelnaui (=A. castelnaui) were also analyzed and showed greater representation of crustaceans and teleosts. The diets of Raja binoculata, $R$. inornata, and $R$. rhina were studied in California (USA), and crustaceans and fish were the most important groups (BIZARRO et al. 2007).

The diets of juveniles and adults overlapped significantly. However, teleost and A. spinicarpus are more important in the diet of adults and Caridea/Dendobranchiata, polychaetes and nematodes are more important in the diet of juveniles. The diets of both sexes were also very similar. Nevertheless, teleost and crabs are slightly more frequent in the diet of females, while males tend to eat more shrimp. These small differences can be attributed to differences in the method of catching food. It is difficult for smaller individuals to capture teleosts, which are more agile (VIANNA et al. 2000).

The temporal analysis of feeding may have been compromised by the low abundance of individuals at certain times of the year, as for instance in Apr-May-Jun 06 and Jul-Aug-Sep 07. However, analysis of the other quarters indicated that there are two groups with similar diets. The water masses found in the region modify the physical and chemical parameters of the water during the seasons, which suggests a change in the structure and dynamics of the benthic fauna in the region (PIRES 1992). Portunidae and A. spinicarpus were the most important groups consumed in Jan-Feb-Mar 06 and Jan-Feb-Mar 07, i.e., the summer of 2006 and the summer of 2007 (when the SACW approaches the coast), which may be explained by the increased availability of $A$. spinicarpus in this region at this time of year (Braga et al. 2005). At Ubatuba, A. spinicarpus is also important in the food of other rajids such as $R$. agassizi and $P$. extenta, especially in the summer, which is related to the local abundance of the species (Muto et al. 2001). Therefore, the period of greatest abundance of $A$. spinicarpus corresponds to the optimal oceanographic conditions for A. cyclophora. The upwelling of SACW may explain the importance of this crab in the diet of the skate. Seasonal changes in diet were observed in other studies of rajids (Muto et al. 2001, BoRnATOWsKi et al. 2010).

Although this study did not analyze a large number of stomachs, the data are important for interpreting the feeding biology of this skate, and to evaluate its responses to environmental conditions and fishing pressures.

\section{ACKNOWLEDGEMENTS}

The authors are grateful to the Laboratório de Biologia e Tecnologia Pesqueira group for the help in samples, measurements and dissection of the skates, to Paulo C. Paiva for helping with polychaete identification, and to Tereza C.G. da Silva and Karina A. Keunecke for helping with crustacean identification.

\section{LITERATURE CITED}

Aguiar, A.A. \& J.L. Valentin. 2010. Biologia e Ecologia Alimentar de Elasmobrânquios no Brasil. Oecologia Australis 14 (2): 464-489. doi:10.4257/oeco.2010.1402.09

Amundsen, P.A.; H.M. Gabler \& F.J. Staldvik. 1996. A new approach to graphical analysis of feeding strategy from stomach contents data-modification of the Costello (1990) method. Journal of Fish Biology 48: 607-614. doi:10.1111/ j.1095-8649.1996.tb01455.x

Bizarro, J.J.; H.J. Robinson; C.S. Rinewalt \& D.A. Ebert. 2007. Comparative feeding ecology of four sympatric skate species off central California, USA. Environmental Biology of Fishes 80 (2-3): 197-220. doi:10.1007/s10641-007-9241-6

Bornatowski, H.; M.C. ROBERT \& L. COSTA. 2010. Feeding of guitarfish Rhinobatos percellens (Walbaum, 1972) (Elasmobranchii, Rhinobatidae), the target of artisanal fishery in Southern Brazil. Brazilian Journal of Oceanography 58 (1): 45-52. doi:10.1590/S1679-87592010000100005

Braga, A.A.; A. Fransozo; G. Bertini \& P.B. Fumis. 2005. Composição e abundância dos caranguejos (Decapoda, Brachyura) nas regiões de Ubatuba e Caraguatatuba, litoral norte paulista, Brasil. Biota Neotropica 5 (2). doi:10.1590/S167606032005000300004

Cheung, W.W.L.; T.J. Pitcher \& D. Pauly. 2005. A fuzzy logic expert system to estimate intrinsic extinction vulnerabilities of marine fishes to fishing. Biological Conservation 124: 97-111. doi:10.1016/j.biocon.2005.01.017

Contes, E. 1997. A critical review of methods of studying fish feeding based on analysis of stomach contents: application to elasmobranch fishes. Canadian Journal of Fisheries and Aquatic Sciences 54: 726-738. doi: 10.1139/f2012-051

Costello, M.J. 1990. Predator feeding strategy and prey importance: a new graphical analysis. Journal of Fish Biology 36: 261-263. doi:10.1111/j.1095-8649.1990.tb05601.x

EBERT, D.A \& J.J BizARro. 2007. Standardized diet compositions and trophic levels of skates (Chondrichthyes: Rajiformes: Rajoidei). Environmental Biology of Fishes 80: 221-237. doi:10.1007/s10641-007-9227-4

Ferry, L.A \& G.M. Cailiet. 1996. Sample size and data analysis: are we characterizing and comparing diet properly?, p. 7180. In: D. Mackinlay \& K. Shearer (Eds). Feeding Ecology and Nutrition in Fish. São Francisco, American Fisheries Society. 
Gomes, U.L.; C.N. Signori; O.B.F. Gadig \& H.R.S. SANTos. 2010. Guia para identificação de tubarões e raias do Rio de Janeiro. Technical Books, Rio de Janeiro. 234p.

HurlberT, S.H. 1978. The measurement of niche overlaps and some relatives. Ecology 59: 67-77. doi:10.2307/1936632

KaWaKami, E. \& G. Vazzoler. 1980. Método gráfico e estimativa de índice alimentar aplicado no estudo de alimentação de peixes. Boletim do Instituto Oceanográfico 29 (2): 205 207. doi: 10.1590/S0373-55241980000200043

Lacerda, L.D.; H.H.M. ParaquetTi; R.V. Marins; C.E. Rezende; I.R. Zalmon; M.P. Gomes \& V. Farias. 2000. Mercury content in shark species from the south-eastern Brazilian coast. Revista Brasileira de Biologia 60 (4): 571-576. doi: 10.1590/ S0034-71082000000400005

Massa, A.; N. Hozbor \& C.M. Vooren. 2006. Atlantoraja cyclophora. In: IUCN (Ed.). Red List of Threatened Species. Version 2009.1. Available online at: http://www.iucnredlist.org [Accessed: 21 july 2009]. doi: 10.1007/978-1-4020-9703-4_8

Muto, E.Y.; L.S.H. Soares \& R. Goitein. 2001. Food resource utilization of the skates Rioraja agassizi (Mûller \& Henle, 1841) and Psammobatis extenta (Garman, 1913) on the Continental shelf off Ubatuba, south-eastern Brazil. Revista Brasileira de Biologia 61 (2): 217-238. doi: 10.1007/978-1-4020-9703-4_8

OdDone, M.C \& C.M. Vooren. 2004. Distribution, abundance and morphometry of Atlantoraja cyclophora (Regan, 1903) (Elasmobranchii: Rajidae) in southern Brazil, Southwestern Atlantic. Neotropical Ichthyology 2 (3): 137-144. doi: 10.1590/S1679-62252004000300005

OdDone, M.C. \& C.M. Vooren. 2005. Reproductive biology of Atlantoraja cyclophora (Regan 1903) (Elasmobranchii: Rajidae) off southern Brazil. ICES Journal of Marine Science 62: 1095-1103.

Oddone, M.C.; W. Norbis; P.L. Mancini \& A.F. Amorim. 2008. Sexual development and reproductive cycle of the Eyespot skate Atlantoraja cyclophora (Regan, 1903) (Condrichthyes: Rajidae: Arhynochobatinae), in southeastern Brazil. Acta Adriatica 49 (1): 73-87. doi: 10.1016/j.icesjms.2005.05.002

PiAnKA, E.R. 1973. The structure of lizard communities. Annual Review of Ecology, Evolution and Systematics 4: 53-74. doi: 10.1146/annurev.es.04.110173.000413

Pires, A.M.S. 1992. Structure and dynamics of benthic megafauna on the continental shelf offshore of Ubatuba, southeastern Brazil. Marine Ecology Progresses Series 86: 63-76. doi: 10.3354/meps086063

Rosecchi, E. \& Y. NouAze. 1987. Comparison de cinq índices alimentaires utilises dans lánalyse des contenus stomacaux. Revue des Travaux de L'institut des Pêches Maritimes 49 (4): 111-123.

Soares, L.S.H.; C.L.B. Rossi-Wongtschowski; L.M.C. Alvares; E.Y. Muto \& M. Los Angeles. 1992. Grupos tróficos de peixes demersais da plataforma continental interna de Ubatuba, Brasil. I. Condrichthyes. Boletim do Instituto Oceanográfico 40 (1/2): doi: 10.1590/S0373-55241992000100006

Vianna, M.; C.A. Arfelli \& A.F. Amorim. 2000. Feeding of Mustelus canis (Elasmobranchii, Triakidae) caught off south-southeast coast of Brazil. Boletim do Instituto de Pesca 26 (1): 7984.

Vooren, C.M. \& S. KLIPPEL. 2005. Diretrizes para a conservação de espécies ameaçadas de elasmobrânquios, p. 213-228. In: C.M. Vooren \& S. Klippel (Eds). Ações para a conservação de tubarões e raias do Brasil. Porto Alegre, Editora Igaré.

WALKER, P.A \& G. HisLop. 1998. Sensitive skates or resilient rays? Spatial and temporal shifts in ray species composition in the central and north-western North Sea between 1930 and the present day. ICES Journal of Marine Science 55: 392402. doi:10.1006/jmsc.1997.0325

ZAVALA-CAMIN, L.A. 1996. Introdução aos estudos sobre alimentação natural em peixes. Maringá, EDUEM, 129p.

Submitted: 30.IX.2013; Accepted: 16.II.2014.

Editorial responsibility: Cassiano Monteiro Neto

ZOOLOGIA 31 (2): 119-125, April, 2014 